\title{
A FELSŐFOKON TANULÓ FÉRFIAK ÉS NŐK TÉRBELI KÖTŐDÉSE EGY REGIONÁLIS MINTÁBAN
}

\author{
(Local and Regional Attachment of Boys and Girls in Choosing \\ Higher Education Institution and the Place of Residence)
}

\author{
FÉNYES HAJNALKA
}

Kulcsszavak:

regionális egyetem területi kötődés nemi különbségek

A tanulmány a felsỏoktatási hallgatók terilleti kötódésének nemi különbségeit vizsgálja. A lokális kötődés kutatása viszonylag kevéssé népszerü a hazai szociológusok körében, és a fogalom pontos definiálása is nehézségekbe ütközik. A térhez való viszony nemi különbségeinek vizsgálatára még kevesebb példát találunk, és a felsöoktatási hallgatók körében alig van ilyen kutatás. Mindezek miatt úgy gondoljuk, hogy munkánk hiánypótló szerepet tölt be, még ha elemzésünk a téma csak egy kis szeletét mutatja is be.

Elsóként a lokális kötỏdésröl írunk, majd bemutatjuk hipotéziseinket. Külön részben írunk a vizsgálati térségröl ( $a$ „Partiumi” régióról), majd ismertetjük a területi kötódésre vonatkozó eddigi eredményeket, melyek a "Regionális egyetem" kutatásból szuilettek. Ezt követi az empirikus vizsgálat a fiúk és lányok térbeli kötödésének különbségeiröl, majd pedig az összegzésben ellenórizzük hipotéziseink helytálló vagy nem helytálló voltát.

\section{A lokális kötődésröl és identitásról általában}

Lokális identitás alatt az egyének vagy csoportok térhez való kötődését értjük (Pálné Kovács 2000). A lokális identitás a társadalmi identitástudat része, az egyén egy földrajzi kategóriákkal meghatảrozható csoport tagjának érzi, vallja magát. A lokális csoporthoz tartozás feltételezi, hogy az egyén a csoport hagyományait, értékrendjét elfogadja és azonosul vele (Murányi-Szoboszlai 2000). Az emberek hajlamosak olyan közösségi szervezetekbe tömörülni, ahol kialakul a valahová tartozás érzése, és kialakul a közösség kulturális identitása is. Sokszor a globalizáció negatív hatásaival szemben alakul ki a területi identitás, így a lokális identitás kiemelt jelentỏséggel bír. A globalizációval szembeni egyetemes reakció a helyi identitás erősödése (kis közösségek önvédelme), ilyenkor a kultúra önvédelmi mechanizmusa lép müködésbe (Petrás 2005a).

A térségi kötődés eleme a rokonsághoz, szomszédsághoz, ismeretségi körhöz, közösséghez való kötődés, és a közös kultúra is összekapcsolja az ott lakókat (Nagy É. 2005). A lokalitás meghatározó eleme emellett a magán közösségi élet, az üzleti hálózat és a hivatalos közélet is. A szomszédsági lét nem feltétlenül esik egybe a település határaival, de érzelmi és szimbolikus jelentése jórészt az egész lokalitásra 
Fényes Hajnalka : A felsőfokon tanuló férfiak és nök térbeli kötődése egy regionális mintában.

Tér és Társadalom 23. évf. 2009/4. 189-206. p.

190 Kitekintö

TÉT XXIII. évf. 2009 - 4

kiterjed. „A helyi identitás fontos elemei a helyi hagyományok, a rokoni, kulturális vagy etnikai összetartozás, valamint a sorsközösség, a történelmi változások közös átélésének tudata." (Petrás 2005a, 20) A lokális közösség, lokális társadalom, helyi közösség, helyi társadalom fogalmak között átfedések vannak. Helyi társadalom kialakulásához szükséges, de nem elégséges feltétel az egy térben élés, a földrajzi összetartozás (Nagy É. 2005).

A lokalitás az emberi élet természetes jelensége. Az emberi társadalom első településformája a község, az együttmüködő szomszédság lakóhelye. „A középkori nyugaton a lokalitás nem pusztán lakóhelyi közösség, hanem önálló, érdekeit a makrotársadalommal szemben kollektívan képviselö egység: helyi társadalom. ... A demokratikus önkormányzatiság lokalizáló folyamata csak akkor jár együtt a valódi helyi társadalom kialakulásával, ha a helyi lakosok felismerik érdekeiket és együttmüködnek közös céljaik megvalósításában." (Petrás 2005a, 14) A szocialista diktatúrák megpróbálták felszámolni a civil társadalom évszázados hagyományát, azonban a rendszerváltás után ez újra elötérbe került.

A területi kötődés típusai Magyarországon az Európai Unióhoz, az országhoz, a régióhoz, a megyéhez, a kistérséghez és végül a településhez való kötődés. Nagy G. D. (é. $\mathrm{n}$.) vizsgálata szerint a szegediek területi kötődésein belül a megye és régió-tudat nem válik el, a régióhoz és megyéhez kötődés mintázata hasonló vonásokat mutat. A faktorelemzés eredményei szerint a két kötődés szorosan kapcsolódik, a válaszadók nem tudnak különbséget tenni a kettő között. (A mi vizsgálatunkban is keveredik a két kötődés-típus.) A szegediek megyéhez és régióhoz kötődése közepes erősségü, a városhoz való kötődésük valamivel erősebb, ettől elválik az országhoz való kötődés, ami szintén elég erős, és végül jelen van egy elég gyenge európai kötödés is (Nagy G. é.n.).

A lokalitást mérhetjük szociometriai módszerekkel (ki kivel van kapcsolatban), azzal, hogy milyen a lakosok lokális kötődése (mit jelent a településhez, helyi közösséghez tartozni), milyen a helyi hagyományok eróssége, a közös múlt ismerete, milyen a település gazdasági helyzete, milyenek a földrajzi és regionális adottságok, és végül, hogy milyen a környezö települések közti együttmüködés (Petrás 2005a).

\section{Hipotézisek és eddigi eredmények}

Napjainkban fontossá vált a közösségben élés (rokoni és baráti kötelékek), mint társadalmi funkció vizsgálata (melyek a térkapcsolatok fontos elemei) a hazai földrajzban. A nemek földrajza a nemek egymáshoz való viszonyát vizsgálja a tér, térhasználat vonatkozásában (Timár 1993).

A hagyományos szerepek diktálta munkamegosztás szerint a férfiak világa a kenyérkereső munka (nyilvános szféra), a privát szféra, a biológiai reprodukció és a háztartási munka viszont a nök színtere. Jellemző tehát a nök nyilvános szférából való kirekesztése. Ennek megfelelóen fontos a lakó- és munkahely szétválása, és a munka 
Fényes Hajnalka : A felsőfokon tanuló férfiak és nök térbeli kötődése egy regionális mintában. Tér és Társadalom 23. évf. 2009/4. 189-206. p.

és a tér nemek szerinti megosztottsága. Az 1960-as években Észak-Amerikában felerösödött a szuburbanizációs folyamat, melynek hatására egyes kutatók megalkották a „feminin szuburbia” és „maszkulin város” modellt, ami azonban Észak-Amerikában is csak a fehér középosztályi családokra volt érvényes (Timâr 1993).

Magyarországon ,nem müködött a 'gyenge nö' védelmét szolgáló, 'maszkulin nyilvános világtól' távoltartó 'édes otthon' ideológiája" (Timár 1993, 12). A szocializmusban teljes foglalkoztatás volt, az urbanizáció megkésettsége volt a jellemző, nem vált szét az amerikaihoz hasonló módon a városi tér. Ekkoriban a kétkeresős családmodell dominált. A nők nagy arányban vettek részt a munka világában, bár a háztartási feladatok nagy része is rájuk hárult. A nemek elválasztását itt a munkahelyek egymáshoz viszonyított térbeli elkülönülése okozta. A térhasználatot inkább befolyásolta a termelésben elfoglalt helyük különbözősége, mint a kenyérkereső és háztartási munka elkülönülése. A férfiak és nők többsége más munkahelyen, más gazdasági ágazatban és területileg is máshol dolgozott. A nők inkább a lakóhelyhez közelebbi munkahelyeket választották, családi feladataik megkönnyítése érdekében (Timár 1993).

A második gazdaság megjelenésével a háztáji munka bizonyos szinten összekapcsolta a férfiak és nők munkájának helyét, és az otthon is termelési szintérré vált. A szocializmusban a nyilvános és privát szféra hagyományos kettéválása csak a gyes bevezetése után a központtól távol esỏ új lakótelepeken valósult meg (Timár 1993).

A rendszerváltás után megjelenő magas munkanélküliséggel a „nőknek otthon a helyük" ideológia terjedését figyelhetjük meg, és sorozatban zártak be a gyermekintézmények. Napjainkban megfigyelhetô a szuburbiákra (kertes házakba) való kiköltözés, ami a nőkre a korábbinál nagyobb terheket ró, megnő az ingázási távolság, a gyermeket nagyobb távolságra kell vinni orvoshoz, iskolába, a gyógyszertár, a patyolat is messzebb van. A nők sokszor növekvő mennyiségü otthon végzett munkával próbálnak segíteni a család rosszabbodó anyagi helyzetén (Timár 1993).

Visszatérve saját vizsgálatunkhoz, mivel hazánkban napjainkban is erősen érvényesülnek a hagyományos nemi szerepek (lásd Pongrácz 2005), ezért azt feltételezzük (elsö hipotézis), hogy a nöknek összességében erösebbek a családi, rokonsági és lokális kötelékei, így a felsőfokú intézmény választásakor ${ }^{1}$, illetve a tervezett lakóhelyet tekintve a felsőoktatásban tanuló lányok térbeli - elsösorban a településhez, de a kistérséghez, megyéhez, régióhoz való - kötódése is erỏsebb lesz, mint a fiúké.

Érdekes jelenség azonban, hogy a férfiak és nők a települési hierarchiában eltérő arányokat mutatnak, a nagyobb településeken nagyobb a nötöbblet. Ennek hátterében egy sajâtos (elsősorban házassági) migrációs folyamat húzódik. A városokban már 35 év felett, míg a falvakban csak 55 év felett jelentkezik a nötöbblet. A fiatal nök kevésbé választják a falusi létformát annak számos hátránya miatt. Az aprófalvakra jellemző, hogy csekély a lakosságszám, az urbánus központoktól nagy a távolság, a közellátások, a források hiánya jellemző. Emellett rosszak a foglalkoztatási lehetőségek, nagy a munkanélküliség, sok nő inaktivitásra kényszerül, több időt töltenek a nők házimunkával. A falusi nőknek az iskolához, egészségügyi ellátáshoz való hozzáférése rosszabb, mint a városban lakóké, és a gyermekintézmények kiépítettsége is kisebb mértékü (Timâr é.n.). 
Fényes Hajnalka : A felsőfokon tanuló férfiak és nök térbeli kötődése egy regionális mintában.

Tér és Társadalom 23. évf. 2009/4. 189-206. p.

Ennek alapján azt is feltételezhetjük (második hipotézis), hogy a tervezett lakóhelyet tekintve a lányok inkább maradnának a felsőfokú intézmény székhelyén, mint esetleg az eredeti falusi lakóhelyen. (Korábbi adataink szerint a felsőfokon tanuló lányok állandó lakhelye nagyobb arányban falu, mint a fiúké [FényesPusztai 2006].) Emellett az is valószínủ, hogy a városokba való migráció a lányoknál inkább kistérségen, illetve megyén belül jelentkezik, míg a fiúk - ha már költöznek - inkább távolabbi városokba mennek. (Ezt adatainkkal úgy tudjuk vizsgálni, hogy a lakóhely és a felsőoktatási intézmény székhelyének különbsége esetén a lányok inkább kistérségen, illetve megyén és régión belül maradnak, míg a fiúk távolabbi térségekből is érkeznek.)

Harmadik hipotézisünk szerint az egyetemi-föiskolai évek alatti ideiglenes migrációban nem számítunk jelentős nemi különbségekre a családalapítás általános kitolódása miatt. A tanulmányok alatti külföldi munkavállalásban és tanulmányútban, illetve a tanulmányaik abbahagyása esetén a tervezett külföldi munkában vagy tanulásban nem lesz számottevő eltérés a férfiak és nők között. (Itt jegyezzük meg, hogy ezen tevékenységek, illetve a tevékenységek tervezése csak kevés diáknál fordul elö, és ez is okozhatja, hogy nem lesz szignifikáns különbség a férfiak és nők között.)

Első hipotézisünk alapján azt is feltételezhetjük, hogy „A felsőfokú intézményválasztásban fontos az intézmény közelsége”, a „Fontos, hogy családhoz, szülökhöz közel éljen”, és a „Fontos ott élni, ahová emlékek, kapcsolatok kötik” mondatokkal a lányok nagyobb arányban értenek majd egyet (negyedik hipotézis).

Végül ötödik hipotézisünk szerint a lakóhelyhez kapcsolódó attitüdök (a közös érdekérvényesítés, a közös tradíciók, a közös hang megtalálása, a könnyủ megközelíthetöség, a szórakozási lehetőségek, a jó elhelyezkedési lehetőségek, a jó lehetôség a családalapításhoz és a vagyonszerzéshez) a lányoknak fontosabbak lesznek, mivel a lokális kötödésük is feltehetőleg erősebb.

$\mathrm{Az}$ eddigi eredmények részben alátámasztják hipotéziseinket, például Bíró Zsuzsanna és Nagy Péter (2007) vizsgálata szerint a két világháború közötti bölcsészkarokon a lányokra inkább jellemző volt a lokális kötődés, majdnem két és félszer annyi férfi szerzett lakóhelyén kívül diplomát, mint nö (a lakóhely székhelye nem egyezett meg az iskola székhelyével). Nagy G. D. (é.n.) már idézett vizsgálatában is a nők kötỏdése valamivel erősebb a megyéhez és a régióhoz (a szegediek körében), mint a férfiaké. További eredménye, hogy a megyéhez és a régióhoz erösebben kötődők között a magasan iskolázottak alulreprezentáltak, és felülreprezentáltak az idősebbek. Horváth (2009) vizsgálata szerint is az idősek jobban kötődnek lakóhelyükhöz, mint a fiatalok, de nemek szerint furcsa módon nem tapasztalt eltérést a felsőtárkányi identitást vizsgálva. 
Fényes Hajnalka : A felsőfokon tanuló férfiak és nők térbeli kötődése egy regionális mintában. Tér és Társadalom 23. évf. 2009/4. 189-206. p.

TÉT XXIII. évf. 2009 『 4

Kitekintö

193

Az adatbázis, a vizsgálati térség jellemzői és a „Regionális egyetem” kutatás célkitüzései

Az elemzésben a Kozma Tamás vezette „Regionális egyetem” kutatás egyik adatbázisát használtuk fel: az ISCED51-et (elsőéves nappali tagozatos föiskolások és egyetemisták, $\mathrm{N}=1587$ fó), mivel a területi kötődést ebben az adatbázisban tudtuk leginkább teljes körúen vizsgálni. (Készült egy negyedéves adatbázis is, de ott kevesebb lokális kötődésre vonatkozó kérdést tettünk fel.) A minta regionális, a „partiumi” térségre (Magyarország egy határ menti régiójára) vonatkozik. Három ország (Magyarország, Románia és Ukrajna) magyar tannyelvü felsőfokú intézményeiben folyt a lekérdezés, az adatfelvétel 2003 és 2005 között zajlott. A ,partiumi”, térségbe a kutatás munkadefiníciója szerint Magyarország két megyéje (HajdúBihar és Szabolcs-Szatmár-Bereg), Románia négy megyéje (Bihar, Szatmár, Máramaros és Szilágy), és Ukrajnából a kárpátaljai rész tartozik.

\section{1. ÁBRA}

A „Regionális egyetem” kutatás során definiált „Partium” térség

(The "Partium" Region Described in the "Regional University" Research Project)

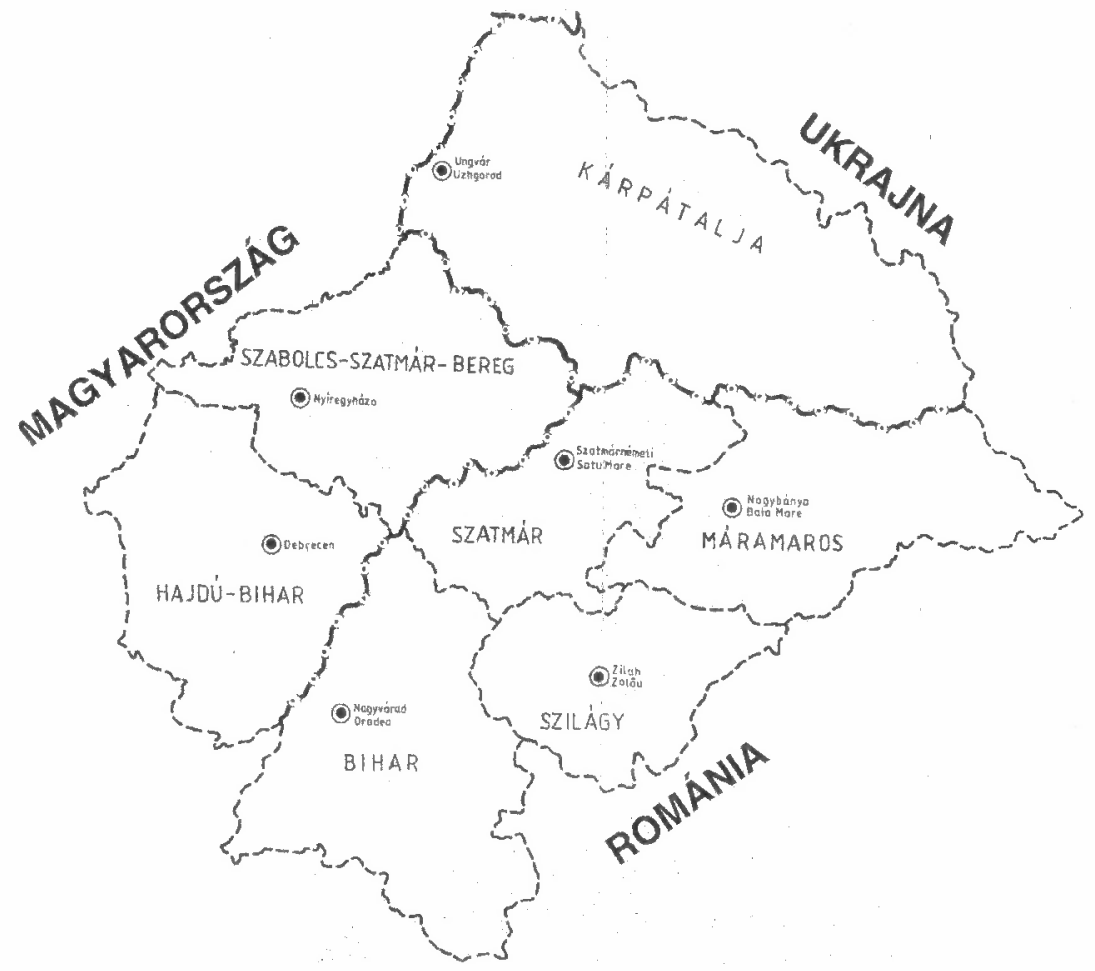

Forrás: Saját szerkesztés. 
Fényes Hajnalka : A felsőfokon tanuló férfiak és nök térbeli kötődése egy regionális mintában.

Tér és Társadalom 23. évf. 2009/4. 189-206. p.

„A régió olyan társadalmi-gazdasági területegységet jelent, amely az öt alkotó ' részek' szoros együttmüködésére és érdekazonosságára épül, de határozott földrajzi határokkal nem minden esetben definiálható." (Süli-Zakar 2005, 12) Egy régióhoz tartozó területet különböző dolgok fognak egységbe, ilyenek a társadalmi-gazdasági folyamatok, az itt élő lakosság regionális identitástudata és a valós önállóságú intézmények rendszere (Süli-Zakar 2005). Emellett összeköti az ott lakókat a közös történelmi múlt, a gazdálkodási mód és szerkezet, az ezekre épülő erös összetartozás, az infrastruktúra többé-kevésbé egységes rendszere, és a népesség tudatában megjelenő régió-tudat is.

„Partium” egy határokon átnyúló régió, Magyarország, Románia és Ukrajna határai mentén helyezkedik el, többnyire a periférián. Ha azonban együttesen vizsgáljuk, akkor földrajzi egységet alkot, amelyet átszelnek az államhatárok (Kozma 2005a). A „Partium” elnevezés még nincs formalizálva, de történeti utalásokat hordoz, és a köznyelvben is használatos, bár politikai elismerést még nem nyert (Kozma 2005b). Lakossága körülbelül 4 millió fö, amelyből 1,7 millió magyar anyanyelvủ (Teperics 2006). A régió magyarországi része periférikus és városhiányos terület. A régió két nagyvárosi központja Debrecen és Nagyvárad, alközpontjai pedig Nyíregyháza, Ungvár és Szatmár (Kozma 2005a).

A ,partiumi" térséget az új határok meghúzását követően a szétszabdalt közlekedési utak, a településszerkezet hiányosságai, a népesség kicsi megtartóereje, a települések agrárjellege és a forráshiány jellemzik. Fontos szerepe van a határokat átszelö kapcsolatok kiépítésében (összekötő régió), bár az egyuittmüködések a kitüzött célokat csak részben tudták elérni, fennmaradt a régió országokon belüli perifériás helyzete (Süli-Zakar 2006).

A „Partiumi” régió speciális vizsgálatát indokolja, hogy például a felsőoktatást tekintve ez egy viszonylag egységes térség. Bár a „Regionális egyetem” kutatás egyik hipotézise az volt, hogy a „Partiumi” régió államai és felsőoktatás-politikái között jelentős különbségek lesznek, az eredmények szerint nincs ,nyugati” (nyugateurópai) vagy „keleti” (szovjet típusú) felsỏoktatás, megfigyelhetỏ, hogy az európai kontinentális és az angolszász modell válik inkább szét. Ukrajna, Románia és Magyarország felsỏoktatása ugyanúgy a kontinentális típusba tartozott (a bolognai rendszer bevezetése előtt). Emellett Kozma (2006) szerint az 1989/1990-es rendszerváltás ${ }^{2}$ hasonlóvá tette a térség felsőoktatás-politikáját, az oktatáspolitika a rendszerváltás részévé vált. A „Partiumi” régió felsőoktatási intézményei a rendszerváltástól az uniós csatlakozásig hasonló történelmi utat jártak be. Az intézmények közti kapcsolatok szorosabbá váltak, és a II. világháború után szétszabdalt gazdasági, társadalmi és oktatási kapcsolatrendszer újjáéledt.

A ,regionális egyetem” olyan intézmény, amely helyi vagy térségi kezdeményezésre alakult, következésképp a helyi-térségi gazdaság és társadalom igényeihez alkalmazkodik (Kozma 2002). „A regionális egyetem vagy föiskola nem országos vagy nemzetközi, hanem térségi vagy helyi; nem a nemzetközi tudományosságot tanítja, hanem a helyben szükséges szakmákat; nem a társadalmi elitet szolgálja, 
Fényes Hajnalka : A felsőfokon tanuló férfiak és nök térbeli kötődése egy regionális mintában. Tér és Társadalom 23. évf. 2009/4. 189-206. p.

TÉT XXIII. évf. 2009 a 4

Kitekintő

195

hanem a helyi gazdaságot és társadalmat; nem nemzetközi kutatásokat végez, hanem a helyi szükségletekre alkalmazott fejlesztéseket." (Kozma 2006, 18)

A „Regionális egyetem” kutatás a magyar tannyelvű felsőoktatást vizsgálta a „Partiumi” térségben. A régió felsőoktatásában négy intézmény játszik fontos szerepet: a Nyíregyházi Főiskola, a Debreceni Egyetem, a nagyváradi Partium Keresztény Egyetem és a beregszászi II. Rákóczi Ferenc Kárpátaljai Magyar Főiskola. A „Regionális egyetem" kutatás központi kérdése, hogy a felsőoktatási intézmények klienseinek milyen a térbeli kötődése, milyen az egyetemek és föiskolák vonzáskörzete.

Az 1990-es években a „Partiumi” térségre jellemző volt a felsőoktatási expanzió, mellyel új oktatási igények születtek. A „regionális egyetem” koncepció szerint regionális szellemi központok kialakítására van szükség, melyek a felsőoktatási intézményhálózatot koordinálják, szükségesnek látszik, hogy a harmadfokú képzést regionálisan szervezni lehessen. A ,regionális egyetem” koncepciónak vannak külföldi elózményei, amerikai és európai példák mutatják a koncepció létjogosultságát (Kozma 2002). A kutatás hipotézise szerint kialakulóban van egy határokon átnyúló, „Partiumi” tanulási régió, ahol a hallgatók a hagyományos képzés mellett újfajta képzéseket és szervezeteket céloznak meg, pl. felnöttképzéseket, szakmai képzéseket, és az itt lévő felsőoktatási intézményekre hosszabb távon az egységesülés jellemző (Kozma 2005a).

A felsőoktatási intézmények (ezen belül is az alföldi föiskolák) térségben betöltött szerepét vizsgálta Petrás (2005b; 2006) is. Eredményei szerint az oktatási intézmények fontos szerepet töltenek be az egyének települési azonosságtudatában, a kisvárosi föiskoláknak helyi társadalomformáló hatása van, emellett a helyi gazdaságra is pozitív hatással vannak.

Összességében elmondható, hogy a „Partium” nem egyszerủen az ország keleti elmaradott térsége, hanem jellemzőek rá közös kulturális szokások, összeköti a térséget a közös múlt és a rendszerváltás után az újjáéledő kulturális és gazdasági kapcsolatok is. Az iskolák és a református gyülekezetek hálózata fontos szerepet játszott a régió kultúrájának és identitásának kialakulásában. Napjainkban megváltozott a határ két oldalán fekvő régiók kapcsolata a NATO bővülés és az EU-hoz való csatlakozás révén, mégis a hét szomszédos ország, Ausztria kivételével centralizált nemzetállamként müködik, a regionålis és helyi kezdeményezéseknek csekély teret hagynak, a határon átnyúló együttműködésekkel szemben nacionalista gyanakvással élnek (Süli-Zakar 2009). A rendszerváltással megnyílt lehetöségek kihasználása lassan halad, mivel a határ menti régiók nem rendelkeznek elegendő önállósággal az együttmüködési programok kidolgozásához, és gyakran kedvezỏtlen gazdasági régiókról van szó, ezért különösen fontos az infrastruktúra és a modernizációt segítő felsỏoktatás fejlesztése. Pozitív tendencia, hogy az oktatásban a határon átnyúló együittmúködések szerepe nőtt, a „regionális egyetemek” megerősödése jellemzö, az utóbbi években nőtt a helyben maradók aránya a térség felsőoktatási intézményeiben (a fiatal értelmiséget ide vonzották) (Süli-Zakar 2009). A nemzeti kisebbségek felsőoktatási igényét különösen Románia és Ukrajna befogadta, és kisebbségi intézmények jöttek létre a rendszerváltás után (a Partium Keresztény Egyetem és a 
Fényes Hajnalka : A felsőfokon tanuló férfiak és nök térbeli kötődése egy regionális mintában.

Tér és Társadalom 23. évf. 2009/4. 189-206. p.

196 Kitekintö

TÉT XXIII. évf. 2009 - 4

beregszászi II. Rákóczi Ferenc Kárpátaljai Magyar Főiskola). Ezek hozzáárultak a városhiányos, depressziós térségek gazdasági fejlödéséhez, a határon átnyúló együttmúködések erősödéséhez. A szimbolikus javak cseréje - köztük az oktatás is - megvalósult, melyet a „regionális egyetemek” bonyolítottak le (Kozma 2006). Sajnos azonban a felsőoktatási intézmények száma és hatóköre jóval elmarad a kívánatostól. Vannak finanszírozási problémák is. Az együttmüködést nehezítik a határ két oldalán fekvő területek gazdasági, intézmény-ellátottsági különbségei, az eltérö mértékü függetlenség és hatáskör (Süli-Zakar 2009).

\section{A „Regionális egyetem” kutatás eddigi eredményei a térbeli kötödésről}

A kutatás megkezdését megelőző vizsgálatok szerint az Észak-alföldi régiót (melybe Jász-Nagykun-Szolnok megye is beletartozik) a gimnáziumi képzés túlsúlya jellemezte a szakképzéssel szemben. A régióban két nagy felsőoktatási intézmény van (a Debreceni Egyetem és a Nyíregyházi Főiskola), és az innovációs szint alacsony a térségben. Jellemző az is, hogy a határon átnyúló kapcsolatok növelték a tanulási igényeket és átformálták a képzési kínálatot (a beregszászi II. Rákóczi Ferenc Kárpátaljai Magyar Föiskola és Partium Keresztény Egyetem létrehozásában a Debreceni Egyetem és a Nyíregyházi Főiskola is szerepet játszott). Hajdú-Bihar megyében a felsőoktatási hallgatókhoz képest alacsonyabb a középiskolába járók aránya, ezért felmerült, hogy a Debreceni Egyetem nem csak regionális szerepkört tölthet be. Azonban a 2002-es elözetes eredmények szerint a Debreceni Egyetemre inkább az Észak-Alföldröl, a Nyíregyházi Föiskolára pedig a régió északkeleti részéröl érkeznek hallgatók, tehát a két felsőoktatási intézmény inkább regionális szerepkörünek látszott (Kozma 2002).

Kérdés tehát, hogy a vizsgálati térségben lévő felsőoktatási intézmények valóban betöltik-e a lokális társadalmi igények kielégítésével kapcsolatos funkciót. A „Regionális egyetem" kutatás első eredményei szerint (Kozma-Pusztai 2006) a térség magyarországi egyetemi hallgatóinak 70\%-a, a föiskolai hallgatóknak 80\%-a Szabolcs-Szatmár-Bereg és Hajdú-Bihar megyében érettségizett. 10\% feletti arányban érkeztek még ide hallgatók az Észak-magyarországi régióból. Legszélesebb vonzáskörzete a Debreceni Egyetem bölcsész és természettudományi karának volt, a többi egyetemi kar 3-4 megyére kiterjedő vonzáskörzettel bír, a föiskolai karokra beiratkozottaknak pedig több mint fele azonos megyében érettségizett. A határon túli intézmények is főként a saját régióból gyűjtötték össze az érettségizett hallgatókat. Összességében tehát az első- és negyedéves egyetemista és föiskolások adatai alapján kimutatható, hogy a régió felsőoktatási intézményeire jellemzó a helyi vonzáskör, regionális jelleg, egyedül a Partium Keresztény Egyetemnek és a Debreceni Egyetemnek tágabb valamivel a vonzáskörzete (kettős arculatú intézmények, egyrészt regionális igényeket elégítenek ki, másrészt a speciális szakterületeken szélesebb vonzáskör jellemzi őket). 
Fényes Hajnalka : A felsőfokon tanuló férfiak és nők térbeli kötődése egy regionális mintában. Tér és Társadalom 23. évf. 2009/4. 189-206. p.

TÉT XXIII. évf. 2009 『 4

Kitekintő

197

Emellett a „Regionális egyetem” kutatás felsőfokú szakképzésben (AISZF) tanulókra vonatkozó adatai alapján kimutatható volt, hogy ha van helyben felsőfokú oktatási lehetőség, a hátrányos helyzetủ rétegek nagyobb arányban próbálják meg a továbbtanulást, a félharmadfokú képzésben való részvétel lehetősége bizonyos mértékig kompenzálja az elmaradott térségböl való származás okozta területi hátrányokat (Pusztai 2006).

Juhász (2006) a kistérség szerepét vizsgálta az iskolaválasztásban a „Regionális egyetem" kutatás negyedéves adatbázisa segítségével. Eredményei szerint a hallgatók jelentős része a debreceni és nyíregyházi kistérségböl származik (309fő a 952-böl). A többség az Észak-alföldi és kisebb részben az Észak-magyarországi régióból jön ide tanulni.

Keller (2008) a határon innen és túl tanuló erdélyi és kárpátaljai diákok lokális kötődését és migrációs terveit vizsgálta. Kimutatta, hogy a helybeli oktatási lehetöségek fékezik a migrációs hajlamot. A szülőföldön maradók magasabbra értékelték a közös lakóhelyen élők együttműködése köré tömörülő szempontokat, a mobil hallgatók azonban alulértékelik ezeket. Eredményei szerint a tervezett elvándorlás (a „Hol élne 10 év múlva?” kérdésre adott válaszok alapján) összefügg a lokalitáshoz füződő attitüdökkel.

Fináncz (é.n.) az EU-s csatlakozással kapcsolatos attitüdöket és a lokális kötődés összefüggéseit vizsgálta. Eredményei szerint a régióhoz nem kötődők optimistábbak voltak az uniós csatlakozás általános hatásaival kapcsolatban, a községben lakók pedig pesszimistábbak voltak a városokban lakóknál. További eredménye, hogy a fiúk optimistábbak voltak az EU-s csatlakozás hatásait illetően, annak ellenére, hogy a regionális kötődésben nem volt szignifikáns különbség nemek szerint. Ennek okát abban látja, hogy a lányok többen laktak falun, és a falusiak negatívabban ítélték meg az EU-s csatlakozást.

Nagy É. (2003) a lokális kötődést és a kulturális fogyasztási lehetőségek kapcsolatát vizsgálta. Megfigyelhető, hogy a településhierarchiában lefelé drasztikusan csökkennek a kulturális fogyasztási lehetôségek. Négy mobilitási csoportot alkotott a „Hol fog élni 10 év múlva?” kérdésre adott válaszok és a középiskola székhelye és a felsőoktatási intézmény székhelye eltérései alapján: a lakóhelyhez kötődő, az elvágyódó, a határon túlról érkező és a régióhoz kötődő típust. Eredményei szerint a mobilitási csoportoknak eltér a kulturális fogyasztása, emellett a helyi szórakozási lehetőségek a régióhoz, lakóhelyhez kötődőknek fontosabbak voltak, továbbá megfigyelhető volt, hogy a diákok összességében előnyben részesítik a lokális kulturális fogyasztást (Nagy É. 2003).

\section{A fiúk és lányok térbeli kötödésének különbségei}

Ahogy láttuk, a vizsgálati térség felsőoktatási intézményei jórészt betöltik regionális szerepkörüket, a hallgatók nagy aránya érkezik a mintaterületen belülröl. A „Partiumi” térségben lakó hallgatók elsősorban a térségben tanulnak felsőfokon, 
Fényes Hajnalka : A felsőfokon tanuló férfiak és nök térbeli kötődése egy regionális mintában.

Tér és Társadalom 23. évf. 2009/4. 189-206. p.

a térségben elérhetö intézményeket preferálják, a két nagyobb felsőoktatási intézmény (Nyíregyházi Főiskola, Debreceni Egyetem) valóban regionális intézménynek tekinthetoo ${ }^{3}$. A térségben élők között egyfajta regionális identitástudat is jelen van (Kozma 2006).

A két világháború közötti bölcsészkarokon Debrecen vonzáskörzete föleg a szomszédos megyék, Északkelet-Magyarország és Székelyföld volt. A nemi különbségeket tekintve a debreceni lakosú nők 4,7\%-a, a férfiak 10,3\%-a nem helyben diplomázott, tehát a nőknek erősebb volt a lokális kötődése. Bíró és Nagy eredményei szerint minél nyugatabbra volt az egyetem, annál több volt a nem helyben diplomázó nő, kivéve Budapestet, ahol a legkisebb volt a felsőfokú végzettséget nem helyben megszerző lányok aránya (Bíró-Nagy 2007).

A továbbiakban az összes vizsgált felsőoktatási intézmény, majd pedig a debreceni, nyíregyházi, hajdúböszörményi és a határon túli intézmények hallgatóinak állandó lakhely szerinti megoszlását tekintjük át, külön a fiúkra és a lányokra. Ezután a kérdöív adta további lehetőségek szerint vizsgálunk néhány kérdést, mely a diákok területi kötődéséhez kapcsolódott.

A felsöoktatási intézmények vonzáskörzete nemi különbségeinek vizsgálata nem azonos a diákok térbeli kötódése nemi különbségeinek vizsgálatával. Korábbi kutatásainkból (Fényes-Pusztai 2006) tudjuk, hogy a lányok rosszabb anyagi helyzetben vannak a vizsgált térség felsőoktatási hallgatói körében, és ez is okozhatja a lakóhelyhez közeli felsőoktatási intézmény választását, nem csak az erősebb lokális kötődés. Vizsgálatunkban ezt a hatást nem tudjuk kiszürni, erre egy további többváltozós elemzésben kerülhet majd sor.

\section{TÁBLÁZAT}

A térség felsöoktatási intézményei hallgatóinak állandó lakhelye nemek szerint, megyei és országos bontásban (\%)

(The Permanent Residence of the Students in the Higher Education Institutions of the Region According to Gender, County and Country [\%])

\begin{tabular}{lccc}
\hline \multicolumn{1}{c}{ Megye (ország) } & $\begin{array}{c}\text { Fiúk } \\
(N=432=100 \%)\end{array}$ & $\begin{array}{c}\text { Lányok } \\
(N=928=100 \%)\end{array}$ & $\begin{array}{c}\text { Összesen } \\
(N=1360=100 \%)\end{array}$ \\
\hline Hajdú-Bihar & 37,5 & 33,3 & 34,6 \\
Szabolcs-Szatmár- & 17,1 & 24,8 & 22,3 \\
Bereg & & & \\
Borsod-Abaúj- & 6,9 & 8,6 & 8,1 \\
Zemplén & & & \\
Jász-Nagykun- & 1,8 & 3,3 & 2,9 \\
Szolnok & 1,8 & 2,6 & 2,3 \\
Békés & 1,6 & 1,8 & 1,8 \\
Heves & 13,9 & 12,2 & 12,7 \\
Románia & 13,4 & 8,8 & 10,3 \\
Ukrajna & 6,0 & 4,6 & 5,0 \\
Egyéb & & & \\
\hline
\end{tabular}

Forrás: „Regionális egyetem” kutatás (2003-2005). 
Fényes Hajnalka : A felsőfokon tanuló férfiak és nők térbeli kötődése egy regionális mintában. Tér és Társadalom 23. évf. 2009/4. 189-206. p.

TÉT XXIII. évf. 2009 - 4

Kitekintő

199

Az 1. táblázatban a térség összes felsőoktatási intézményébe járó hallgatók állandó lakhelyét vizsgáljuk. Amint látható, a fiúk aránya a lányokhoz képest nagyobb a Hajdú-Bihar megyéből érkezők között, a lányok aránya viszont a Szabolcs-SzatmárBereg megyéböl érkezők körében magasabb, mint a fiúké. (Bár mindkét nem inkább Hajdú-Biharból érkezik a térség felsőoktatási intézményeibe.) Románia és Ukrajna szerepel még 10\% feletti értékekkel (feltehetőleg ezen hallgatók többsége a Partium Keresztény Egyetemen és a beregszászi II. Rákóczi Ferenc Kárpátaljai Magyar Föiskolán tanul). Három megyéböl (Borsod-Abaúj-Zemplén, Jász-Nagykun-Szolnok és Békés) 2-10\% között jönnek hallgatók, és a lányok arányaiban valamivel többen érkeznek ezekből a megyékből, tehát úgy tünhet, hogy területi mobilitásuk valamivel nagyobb. Ha azonban a többi, még távolabbi megyéket is tekintjük (az „egyéb” kategóriát) a fiúk valamivel nagyobb arányban érkeznek innen.

Összességében a régió felsőoktatási intézményeinek vonzáskörzete (a régiós kötődés) hasonlóan alakul a két nemnél. Megfigyelhetỏ azonban, hogy míg a fiúk inkább Hajdú-Bihar, addig a lányok inkább Szabolcs-Szatmár-Bereg megyéből érkeznek a régióba tanulni (az egymáshoz viszonyított arányokat tekintve), valamint az is látható, hogy a régión kívüli megyékből a közelebbi megyék esetén inkább a lányok, a távolabbiak esetén pedig inkább a fiúk jönnek nagyobb arányban.

A következőkben (2. táblázat) a debreceni székhelyü intézmények (Debreceni Egyetem, Kölcsey Ferenc Református Tanárképzỏ Föiskola [KFRTF]) vonzáskörzetét tekintjük át megyei (országos, néhol kistérségi) és nemi bontásban (a Hajdúböszörményi Főiskolát, mely a Debreceni Egyetem része, külön vizsgáljuk majd).

\section{TÁBLÁZAT}

A Debreceni Egyetem (Hajdúböszzörményi Kar nélkül, KFRTF-fel együtt) hallgatóinak állandó lakhelye nemek szerint megyei és országos bontásban (\%)

(The Permanent Residence of the Students of Debrecen University and the Ferenc Kölcsey Teacher Training College, (Hajdúböszörmény Faculty Ommited) According to Gender, County and Country [\%])

\begin{tabular}{lccc}
\hline \multicolumn{1}{c}{ Megye (Ország) } & $\begin{array}{c}\text { Fiúk } \\
(N=285=100 \%)\end{array}$ & $\begin{array}{c}\text { Lányok } \\
(N=531=100 \%)\end{array}$ & $\begin{array}{c}\text { Összesen } \\
(N=816=100 \%)\end{array}$ \\
\hline $\begin{array}{l}\text { Hajdú-Bihar } \\
\quad \text { ebböl a Debre- }\end{array}$ & 53,9 & 45,8 & 48,6 \\
$\begin{array}{l}\text { ceni kistérség } \\
\text { Szabolcs-Szatmár- }\end{array}$ & 40,4 & 30,7 & 34,1 \\
$\begin{array}{l}\text { Bereg } \\
\text { Borsod-Abaúj- }\end{array}$ & 20,9 & 24,2 & 23,2 \\
Zemplén & 8,3 & 8,8 & 8,6 \\
Jász-Nagykun- & & & \\
Szolnok & 2,9 & 4,9 & 4,1 \\
Békés & 2,9 & 3,7 & 3,3 \\
Ukrajna & 1,8 & 2,6 & 2,3 \\
Budapest & 1,1 & 1,3 & 1,2 \\
Egyéb & 8,2 & 8,7 & 8,7 \\
\hline
\end{tabular}

Forrás: „Regionális egyetem” kutatás (2003-2005). 
Fényes Hajnalka : A felsőfokon tanuló férfiak és nök térbeli kötődése egy regionális mintában.

Tér és Társadalom 23. évf. 2009/4. 189-206. p.

Amint látható, hipotézisünkkel szemben a fiúk nagyobb arányban érkeznek HajdúBihar megyéböl, illetve a Debreceni kistérségből Debrecenbe tanulni, mint a lányok (majdnem 10\%-os a különbség), lokális kötődésük tehát erösebbnek tünik, a lányok aránya viszont magasabb a fiúkénál a Szabolcs-Szatmár-Bereg megyéből érkezők között. A szabolcsi lányok nagy aránya a Debreceni Egyetemen azért is meglepó, mert Szabolcs-Szatmár-Bereg megyében található a Nyíregyházi Főiskola is, ahol a tanulók nagy többsége (80\%-a) lány. A hipotézisünknek ellentmondó eredmények hátterében az állhat, hogy a szabolcsi fiúk inkább a Miskolci Egyetemet - illetve ott is a múszaki képzést - célozzák meg, a Debreceni Egyetemen ezért kisebb az arányuk (2003-ban, amikor a lekérdezés folyt, a vizsgált térségben nem volt Mủszaki Egyetem, csak Müszaki Föiskolai Kar [a Debreceni Egyetemen belül]).

$\mathrm{Az}$ is látható, hogy a debreceni felsőoktatási intézmények vonzáskörzete 70\%-ban (lányok) illetve 75\%-ban (fiúk) a „Partiumi” régión belül van. A régión kívüli megyék közül Jász-Nagykun-Szolnok megye esetében kicsit nagyobb a lányok aránya, a többi megye esetén azonban elenyésző a különbség nemek szerint.

Következő táblázatunk (3. táblázat) a Nyíregyházi Főiskola vonzáskörzetének nemi különbségeit mutatja.

\section{TÁBLÁZAT}

A Nyíregyházi Egészségügyi Föiskola és a Nyirregyházi Tanárképzö Föiskola hallgatóinak állandó lakhelye nemek szerint megyei bontásban (\%)

(The Permanent Residence of the Students of the College for Health Workers and the Teacher Training College of Nyíregyháza According to Gender and County [\%])

\begin{tabular}{lccc}
\hline \multicolumn{1}{c}{ Megye } & $\begin{array}{c}\text { Fiúk } \\
(N=32=100 \%)\end{array}$ & $\begin{array}{c}\text { Lányok } \\
(N=124=100 \%)\end{array}$ & $\begin{array}{c}\text { Összesen } \\
(N=156=100 \%)\end{array}$ \\
\hline $\begin{array}{l}\text { Szabolcs-Szatmár- } \\
\text { Bereg }\end{array}$ & 46,9 & 59,7 & 57,1 \\
$\quad$ ebböl a Nyíregy- & 28,1 & 32,3 & 31,4 \\
házi kistérség & 18,7 & 18,5 & 18,5 \\
Hajdú-Bihar & 21,8 & 16,1 & 16,6 \\
Borsod-Abaúj- & 12,6 & 5,7 & 7,8 \\
Zemplén & Egyéb & & \\
\hline
\end{tabular}

Forrás: „Regionális egyetem” kutatás (2003-2005).

Amint látható, a lányok nagyobb arányban jönnek Szabolcs-Szatmár-Bereg megyéből, illetve a Nyíregyházi kistérségből ide tanulni, mint a fiúk. A HajdúBihar megyéböl érkezettek között hasonlóak a nemi arányok, a Borsod-AbaújZemplén megyéből, illetve a más - régión kívüli - megyékből viszont a fiúk jönnek ide nagyobb arányban. Itt tehát érvényesül hipotézisünk, miszerint a lányok inkább a közeli kistérségből, megyéből érkeznek, míg a fiúk inkább a távolabbi térségekböl. A két nyíregyházi intézménybe összességében a fiúk 34,4\%-a, a lányok 21,8\%-a érkezik a régión kívülről. Összességében a diákok $75,6 \%$-a lakik az általunk definiált régión belül, hasonlóan a debreceni intézményekhez. 
Fényes Hajnalka : A felsőfokon tanuló férfiak és nök térbeli kötődése egy regionális mintában. Tér és Társadalom 23. évf. 2009/4. 189-206. p.

A 4. táblázatban a Hajdúböszörményi Föiskola diákjai állandó lakhelyének nemi különbségeit vizsgáljuk.

\section{TÁBLÁZAT}

A Debreceni Egyetem Hajdúböszörményi Föiskolai Kar hallgatóinak állandó lakhelye nemek szerint megyei bontásban (\%)

(The Permanent Residence of the Students of Hajdüböszörmény College of Debrecen University According to Gender and County [\%])

\begin{tabular}{lccc}
\hline \multicolumn{1}{c}{ Megye } & $\begin{array}{c}\text { Fiúk } \\
(N=2=100 \%)\end{array}$ & $\begin{array}{c}\text { Lányok } \\
(N=93=100 \%)\end{array}$ & $\begin{array}{c}\text { Összesen } \\
(N=95=100 \%)\end{array}$ \\
\hline $\begin{array}{l}\text { Hajdú-Bihar } \\
\quad \text { ebböl a Hajdúbö- }\end{array}$ & 100 & 46,3 & 47,4 \\
$\begin{array}{l}\text { szörményi kistérség } \\
\text { Szabolcs-Szatmár- }\end{array}$ & 50 & 11,8 & 12,6 \\
$\begin{array}{l}\text { Bereg } \\
\text { Egyéb }\end{array}$ & - & 29,3 & 28,6 \\
\hline
\end{tabular}

Forrás: „Regionális egyetem” kutatás (2003-2005).

Látható, hogy összesen két fiú tanul itt, akik Hajdú-Bihar megyéböl érkeztek, így e képzőintézmény esetében nem érdemes a nemi különbségeket vizsgálni. A lányok 46,3\%-a érkezik szintén ebböl a megyéből, $11,8 \%$-uk a hajdúböszörményi kistérségböl. A hallgatók többsége ( $76 \%$-a) a régióból érkezik, tehát a föiskola betölti regionális szerepkörét, hasonlóan a nyíregyházi és a debreceni intézményekhez.

A vizsgált két határon túli intézmény esetén az intézmények területi elhelyezkedésével összhangban a Partium Keresztény Egyetem hallgatói 100\%-ban Romániából, illetve a beregszászi II. Rákóczi Ferenc Kárpátaljai Magyar Föiskola hallgatói 99\%-ban Ukrajnából érkeznek (a beregszászi fơiskolán egy diák a debreceni kistérségböl érkezett). (Az adatok részletesebb bemutatására jelen tanulmány keretein belül nem kerül sor.)

A továbbiakban néhány - szintén a diákok térbeli kötődését mutató - változót vizsgálunk meg nemi bontásban az elsőéves ISCED51 adatbázis alapján.

Összhangban hipotézisünkkel nincs szignifikáns különbség nemenként a „Dolgozott-e külföldön”? „Tanult-e külföldön?” kérdésnél, illetve a fiúk és lányok ugyanolyan arányban akarnak tanulmányaik abbahagyása esetén külföldön dolgozni. A külföldi tanulmányút tervezésénél a lányok vannak előnyben, bár ahogy látható, összességben ilyen tervei a diákok kis százalékának voltak (5. táblázat). Az ideiglenes migrációnál tehát - hipotézisünkkel összhangban - nem kaptunk jelentös nemi különbségeket.

Következő vizsgálatunk szerint - negyedik hipotézisünkkel szemben - a felsőfokú intézményválasztásnál az intézmény közelségét hasonló arányban tartották fontosnak a fiúk és a lányok. Ugyancsak hasonló arányban mondták azt mindkét nem képviselöi, hogy fontos, hogy családjukhoz, szüleikhez közel éljenek. (Mivel az eredmények nemek szerint nem különböznek szignifikánsan, az adatok bemutatásától eltekintünk.) Szintén hipotézisünknek ellentmondó eredmény, hogy a fiúk nagyobb arányban szeretnének ott élni, ahová emlékek, kapcsolatok kötik őket (6. táblázat). 
Fényes Hajnalka : A felsőfokon tanuló férfiak és nök térbeli kötődése egy regionális mintában. Tér és Társadalom 23. évf. 2009/4. 189-206. p.

Ennek magyarázata az lehet, hogy ezek inkább „puhább” kérdések, a diákok attitűdjére vonatkoznak, és itt még nem válik el élesen a két nem területi kötődésének jellege. A következő kérdésnél (Hol szeretne élni 10 év múlva?) viszont már feltehetőleg a tényleges területi kötődést tudjuk vizsgálni.

\section{TÁBLÁZAT}

A „Tanulmányai abbahagyása esetén külföldre menne tanulni” válasz választása nemenként

(Choosing the Answer "In Case of Dropping out I Would Go abroad to Study" According to Gender)

\begin{tabular}{lccc}
\hline & Fiú & Lány & Összesen \\
\hline Választotta (\%) & 3,8 & 8,4 & 6,9 \\
Nem választotta & 96,2 & 91,6 & 93,1 \\
$(\%)$ & 468 & 971 & 1439 \\
$\mathrm{~N}$ (fö) & & & \\
\hline
\end{tabular}

Chi négyzet ** szinten szignifikáns

Forrás: „Regionális egyetem” kutatás (2003-2005).

\section{TÁBLÁZAT}

Az „Ott éljen, ahová emlékek, kapcsolatok kötik” válasz választása nemenként (Choosing the Answer "I Would Live where I am Attached to by Memories and Relations" According to Gender)

\begin{tabular}{lccc}
\hline & Fiú & Lány & Összesen \\
\hline Választotta (\%) & 12,2 & 7,1 & 8,7 \\
Nem választotta (\%) & 87,8 & 92,9 & 91,3 \\
$\mathrm{~N}$ (fö) & 376 & 830 & 1206 \\
\hline
\end{tabular}

Chi-négyzet ** szinten szignifikáns

Forrás: „Regionális egyetem” kutatás (2003-2005).

\section{TÁBLÁZAT}

A „Hol szeretne élni 10 év múlva?" kérdésre adott válaszok nemi bontásban (\%)

(The Responses to the Question "Where Would You Like to Live in Ten Years?" According to Gender [\%])

\begin{tabular}{|c|c|c|c|}
\hline & Fiú & Lány & $\begin{array}{c}\ddot{O}_{s s z e-} \\
\text { sen }\end{array}$ \\
\hline Ez a kérdés számomra nem lényeges & 36,5 & 28,1 & 30,9 \\
\hline Ugyanabban a házban/lakásban, ahol most & 6,2 & 3,2 & 4,2 \\
\hline Ugyanazon a településen, ahol most & 23,5 & 24,3 & 24,1 \\
\hline Ugyanazon a településen, ahol tanul & 10,2 & 15,9 & 14 \\
\hline $\begin{array}{l}\text { Sem ott, ahol jelenleg tanul, sem ott, } \\
\text { ahol jelenleg lakik }\end{array}$ & 23,7 & 28,5 & 26,9 \\
\hline$N\left(f_{o}^{\prime \prime}\right)$ & 452 & 945 & 1397 \\
\hline
\end{tabular}

Chi-négyzet *** szinten szignifikáns

Forrás: „Regionális egyetem” kutatás (2003-2005). 
Fényes Hajnalka : A felsőfokon tanuló férfiak és nök térbeli kötődése egy regionális mintában. Tér és Társadalom 23. évf. 2009/4. 189-206. p.

Látható, hogy nemek szerint szignifikáns különbség van a fenti kérdésre adott válasznál. Bár a településhez (állandó lakóhelyhez) való kötődés nemenként hasonló arányokat mutat, a felsőoktatási intézmény székhelyén a lányok nagyobb arányban telepednének le (ez összhangban van második hipotézisünkkel, miszerint a lányok eredeti falusi lakóhelyüket felcserélnék az intézmény székhelyével). A lakás/vagy házhoz való kötödés mindkét nemnél gyenge, ahogy ez várható is a többségben családalapítás előtt álló fiataloknál. Érdekes, hogy lakóhelyéről és tanulási helyéről elvándorolna a lányok 28,5\%-a, míg a fiúknak csak 23,7\%-a, viszont a fiúk nagyobb részének ez a kérdés (mármint a tervezett lakóhely elhelyezkedése) nem lényeges. Összességben a lányoknak valamivel fontosabb, hogy hol fognak élni, és jobban kötődnek az iskola székhelyéhez, mint a fiúk. Hipotézisünkkel szemben azonban valamivel nagyobb közöttük az elvándorlás tervezése, bár lehet, hogy ennek hátterében az áll, hogy azok a fiúk, akiknek ez a kérdés most még nem lényeges, valójában inkább elvándorolnak majd, mint a lányok.

Az elvándorlással összefüggésben lehet az, hogy a fiúknak és lányoknak mi a fontos a lakóhelyükkel kapcsolatban. A következő kérdés ezt vizsgálja (8. táblázat).

\section{TÁBLÁZAT}

„Fontos a lakóhelyén..." kérdésre adott válaszok átlaga (1-10) nemenként

(The Average of the Responses (1-10) to the Question "It is Important at You Residence..." According to Gender)

\begin{tabular}{lccc}
\hline & Fiú $(N)$ & Lány $(N)$ & ANOVA \\
\hline Szórakozási lehetőségek & $8,24(466)$ & $8,69(977)$ & $* * *$ \\
Könnyủ megközelíthetőség & $8,24(465)$ & $8,52(976)$ & $*$ \\
Közös hang megtalálása & $7,28(465)$ & $7,64(973)$ & $* *$ \\
Közös érdekérvényesítés & $6,32(463)$ & $6,77(970)$ & $* *$ \\
Közös tradíciók tartsák össze & $5,76(461)$ & $6,13(975)$ & $*$ \\
Jó elhelyezkedési lehetöség & $4,97(463)$ & $4,41(978)$ & $* *$ \\
a fiataloknak & $4,98(463)$ & $5,02(978)$ & NS \\
Jó lehető́ség a családalapításhoz & $4,05(464)$ & $3,8(977)$ & NS \\
Jó lehetöség a vagyonszerzéshez & $4,05(46)$ & &
\end{tabular}

Forrás: „Regionális egyetem” kutatás (2003-2005).

Adataink szerint a településhez kapcsolódó attitüdök alapján a diákoknak a közös tradícióknál fontosabbak a terület nyújtotta lehetöségek. Látható, hogy a legfontosabb tényezők a könnyü megközelíthetőség és a szórakozási lehetőségek, illetve ennél valamivel kevésbé fontos, de fontos a közös érdekérvényesítés, a közös tradíciók, a közös hang megtalálása. Látható az is, hogy ez az öt tényezỏ a lányoknak fontosabb, mint a fiúknak. Ez az eredmény összhangban van ötödik hipotézisünkkel, miszerint a lányoknak fontosabb a lokalitás, és olyan településen akarnak majd élni, ahol a fenti a szempontok érvényesülnek.

A fenti öt szempontnál kevésbé fontos szempont a jó elhelyezkedési esély a lakóhelyen, ami viszont a fiúknak fontosabb, összhangban a hagyományos nemi szerepekkel (a férfi szerepe a megélhetés biztositása), emellett kimutatható az is, hogy minkét nem hasonló arányban tarja fontosnak a jó lehetőséget a családalapításhoz és vagyonszerzéshez, de ezeket az első öt tényezőnél kisebb mértékben. 
Fényes Hajnalka : A felsőfokon tanuló férfiak és nök térbeli kötődése egy regionális mintában.

Tér és Társadalom 23. évf. 2009/4. 189-206. p.

\section{Összegzés}

Kutatásunk első lépcsőjében a vizsgált térség felsőfokú intézményei vonzáskörzetének nemi különbségeit vizsgáltuk. A vonzáskörzet vizsgálata nem teljesen azonos a térbeli kötödés vizsgálatával, a felsőfokú intézmények választásánál a fiúk és lányok nem csak térbeli kötődésük eltérése miatt döntenek az egyik vagy másik intézmény mellett. Ebben az intézmények típusa, elérhetösége és a hallgatók anyagi helyzete is közrejátszik. Hipotézisünkben a lányok erősebb térbeli kötődését feltételeztük, de a vonzáskörzetek vizsgálatánál azt is számításba kell vennünk, hogy a térségben tanuló lányok anyagi helyzete rosszabb, mint a fiúké (lásd Fényes-Pusztai 2006), tehát ez is okozhatja a lakóhelyhez közeli intézmények választását. Ezt a hatást jelen elemzésünkben nem tudtuk elkülöníteni, erre csak egy többváltozós vizsgálatban kerülhet majd sor.

Összességében a régió felsőoktatási intézményei betöltik regionális szerepkörüket, de megfigyelhető, hogy míg a fiúk aránya a Hajdú-Bihar, addig a lányok aránya a Szabolcs-Szatmár-Bereg megyéből érkezők között magasabb (az egymáshoz viszonyított arányokat tekintve). A jelenség oka lehet, hogy a szabolcsi fiúk inkább a Miskolci Egyetemet (fóleg a Múszaki Egyetemet) célozzák meg, mivel a vizsgálati térségben nem volt Müszaki Egyetem, csak Műszaki Főiskolai Kar. (A Hajdú-Bihar megyei fiúk viszont inkább Debrecenbe mennek tanulni, és a régión belül maradnak.) Hipotéziseinkkel összhangban megfigyelhetö az is, hogy a régión kívüli megyék közül a lányok inkább a közelebbi megyékböl, míg a fiúk a távolabbi megyékböl érkeznek a térségbe tanulni.

A két nyíregyházi intézménybe, hipotézisünkkel összhangban, a lányok a fiúknál nagyobb arányban érkeznek Szabolcs-Szatmár-Bereg megyéböl, illetve a Nyíregyházi kistérségböl, tehát jobban kötődnek a megyéhez és a kistérséghez, mint a fiúk. Borsod-Abaúj-Zemplén megyéböl, illetve a más - régión kívüli - megyékböl viszont a fiúk jönnek ide nagyobb arányban.

A Hajdúböszörményi Föiskola diákjainak több mint 98\%-a lány, így itt nem volt érdemes a nemek területi kötódésének különbségeit vizsgálni, viszont fontos eredmény, hogy a hallgatók többsége a régióból érkezett, tehát a föiskola betölti regionális szerepkörét. A két határon túli intézmény esetén a diákok majdnem 100\%-a romániai, illetve ukrajnai lakóhellyel rendelkezett (esetükben nem rendelkeztünk megyei vagy kistérségi adatokkal), így itt sem volt érdemes a nemi különbségeket vizsgálni.

A külföldi munkavállalás vagy tanulás terve hasonló mértékben jellemzö mindkét nemre, és tanulmányaik abbahagyása esetén hasonló arányban akarnak küllföldön dolgozni, külföldi tanulmányutat viszont a lányok terveztek kicsit gyakrabban. Ezek az eredmények az ideiglenes térbeli elmozdulásra vonatkoznak, ahol nem számítottunk nagy nemi különbségekre (a harmadik hipotézis igazolódott). Negyedik hipotézisiinkkel szemben azonban nem volt különbség nemek szerint azok arányában, akik a felsőfokú intézményválasztásnál az intézmény közelségét tartották fontosnak, és nem volt nemek szerint különbség a ,fontos, hogy a családjához, szüleihez közel 
Fényes Hajnalka : A felsőfokon tanuló férfiak és nök térbeli kötődése egy regionális mintában. Tér és Társadalom 23. évf. 2009/4. 189-206. p.

éljen" változónál sem. Emellett kimutatható volt, hogy a fiúk nagyobb arányban szeretnének ott élni, ahová emlékek, kapcsolatok kötik őket. A fenti attitüdökben tehát várakozásainknak ellentmondó eredményeket kaptunk.

A „Hol szeretne élni 10 év múlva?” kérdés azonban már a konkrét tervekre vonatkozik, és itt jelentős különbségek mutatkoztak nemek szerint. Bár a tervezett lakóhely vonatkozásában a mostani lakóhelyhez való kötődés nemenként hasonló arányokat mutat, a felsőoktatási intézmény székhelyén a lányok nagyobb arányban telepednének le, összhangban második hipotézisünkkel. Emellett a lányoknak valamivel fontosabb volt, hogy hol fognak élni (a fiúk több mint harmadának ez a kérdés nem lényeges), viszont nem akar lakni sem a mostani lakóhelyén, sem az iskola székhelyén a lányok majdnem harmada (a fiúknak csak negyede választotta ezt a lehetőséget). A hipotézisünknek ellentmondó eredmény hátterében az állhat, hogy azok a fiúk, akiknek ez a kérdés most még nem lényeges, valójában inkább elvándorolnak majd, mint a lányok.

Ötödik hipotézisünkkel összhangban a lakóhelyhez kötődő attitüdök a lányoknak fontosabbak voltak, öt tényezőt ők említettek gyakrabban, és csak a jó elhelyezkedési esélyt tartották fontosabbnak a fiúk (ami a hagyományos nemi szerepek továbbélését jelzi). A lányoknak fontosabb a lakóhelyükön a közös érdekérvényesítés, a közös tradíciók, a közös hang megtalálása, a könnyü megközelíthetőség és a szórakozási lehetőségek, olyan településen akarnak élni, ahol a fenti szempontok érvényesülnek.

Összességében a „Regionális egyetem” kutatás lehetőségein belül számos változó mentén tudtuk vizsgálni a fiúk és lányok térbeli kötődését, és néhány hipotézisünknek ellentmondó eredmény mellett összességében kimutatható volt, hogy a lányok valamivel jobban kötődnek a lakóhelyükhöz, illetve az iskola székhelyéhez, mint a fiúk (bár a lányok rosszabb anyagi háttér-mutatóinak hatását ebben a vizsgálatban nem tudtuk kiszürni). Az eredmények összhangban vannak más kutatások eredményeivel, bár a hazai szakirodalomban viszonylag kevés vizsgálat nézte a térbeli kötődés nemi különbségeit. Reméljük, hogy eredményeink hozzájárulnak ennek a kérdéskörnek az alaposabb vizsgálatához.

\section{Jegyzetek}

${ }^{1}$ Tanulmányunk empirikus részében a felsőfokú intézmények vonzáskörzetének nemi különbségeit is vizsgáljuk. A vonzáskörzet vizsgálata nem azonos a térbeli kötődés vizsgálatával, hiszen az intézményválasztásban egyéb tényezök (anyagi helyzet, elérhetőség), illetve a felsőfokú intézmény jellege is közrejátszik. Erre az eredményeknél és az összegzésben még kitérünk.

${ }^{2}$ Romániában forradalomnak, illetve Ukrajnában nemzeti újjászületésnek is nevezik ezt az idószakot.

${ }^{3}$ Bár a Partium Keresztény Egyetemnek és a Debreceni Egyetemnek valamivel tágabb a vonzáskörzete, mint a térségben lévő többi fỏiskolának. 
Fényes Hajnalka : A felsőfokon tanuló férfiak és nök térbeli kötődése egy regionális mintában.

Tér és Társadalom 23. évf. 2009/4. 189-206. p.

\section{Irodalom}

Bíró Zs.H.-Nagy P.T. (2007) Nemi esélyek és nemi döntések a két világháború közötti bölcsészkarokon. - Educatio. 4. 565-590. o.

Fináncz J. (é.n.) Európai Unióval kapcsolatos attitúdök a regionális kötődés tükrében. http://dragon.unideb.hu/nevtud/Regionalis/Kapcsanyag/EUs_attitudok.pdf

Fényes H.-Pusztai G. (2006) Férfiak hátránya a felsőoktatásban egy regionális minta tuikrében. - Szociológiai Szemle. 1. 40-59. o.

Horváth T. (2009) A felsótárkányi identitás elemzése. Szakdolgozat. Debreceni Egyetem Szociológia és Szociálpolitika Tanszék, Debrecen.

Juhász A. (2006) Regionális egyetem, lokális identitás. - Juhász E. (szerk.) Régió és oktatás. A „Regionális egyetem" kutatás zárókonferenciájának tanulmánykötete. Doktoranduszok Kiss Árpád Közhasznú Egyesülete, Debrecen. 383-390. o.

Keller M. (2008) Lokális kötődés és tanulmányi célú migráció. - Educatio. 3. 449-452. o.

Kozma T. (2002) Regionális egyetem. Kutatás közben. No. 233. Oktatáskutató Intézet, Budapest.

Kozma T. (2005a) Felsỏfokú képzés és regionális rendszerváltozás. - Pusztai G. (szerk.) Régió és oktatás. Doktoranduszok Kiss Árpád Közhasznú Egyesülete, Debrecen. 23-31. o.

Kozma T. (2005b) Kisebbségi oktatás Közép-Európában. Új Mandátum Könyvkiadó, Budapest.

Kozma T. (2006) Regionális átalakulás és térségi visszhang. A „partiumi” felsỏoktatás esete. - Juhász E. (szerk.) Régió és oktatás. Doktoranduszok Kiss Árpád Közhasznú Egyesülete, Debrecen 13-25, o.

Kozma T.-Pusztai G. (2006) Hallgatók a határon. Észak-alföldi, kárpátaljai és partiumi főiskolások továbbtanulási igényeinek összehasonlító vizsgálata. - Kelemen E.-Falus I. (szerk.) Tanulmányok a neveléstudomány köréból. Műszaki Kiadó, Budapest. 423-453. o.

Murányi I.-Szoboszlai Zs. (2000) Identitás-jellemezők a Dél-alföldi régióban. - Tér és Társadalom. 1. 28-50, o.

Nagy É.(2003) „Kultúr-tér” - avagy a lokális szempontok helye és szerepe a kulturális fogyasztás folyamatában. - Educatio. 2. 297-322. o.

Nagy É. (2005) A regionális identitás megjelenésének vizsgálata. - Pusztai G. (szerk.) Régió és oktatás. Európai dimenzióban. Doktoranduszok Kiss Árpád Közhasznú Egyesuilete, Debrecen. 66-77. o.

Nagy G.D. (é.n.) A szegediek terilleti kötödései. http:/www.sze.hu/mtdi/gyoreuropa/R\%E9sztematik\% Elk/Nagy\%20G\%Elbor\%20D\%E1niel\%20dolg.doc

Pálné Kovács I. (2000) Régiók Magyarországa: utópia vagy ultimátum? - Horváth Gy.-Rechnitzer J. (szerk.) Magyarország teriileti szerkezete és folyamatai az ezredfordulón. MTA Regionális Kutatások Központja, Pécs. 73-93. o.

Petrás E. (2005a) Lokalizáció: globalis alternativa? http://dragon.unideb.hu/nevtud/Regionalis/ Kapcsanyag/lokaizacio.pdf

Petrás E. (2005b) Lokalizáció és lokális identitás a globalizáció korában. - Szociológiai Szemle . 4. 85-98. o.

Petrás E. (2006) Intézmény és lokalitás: A kisvárosi fỏiskolák helyi társadalomformáló hatása. - Juhász E. (szerk.) Régió és oktatás. A „regionális egyetem” kutatás zárókonferenciájának tanulmánykötete. Doktoranduszok Kiss Árpád Közhasznú Egyesülete, Debrecen. 391-402. o.

Pongrácz T.-né (2005) Nemi szerepek társadalmi megítélése. Egy nemzetkőzi összehasonlító vizsgálat tapasztalatai. - Nagy I.-Pongrácz T.-né-Tóth I.Gy. (szerk.) Szerepváltozások. Jelentés a nők és férfiak helyzetéról 2005. TÁRKI - Ifjúsági, Családügyi, Szociális és Esélyegyenlöségi Minisztérium, Budapest. 73-86. o.

Pusztai G. (2006) Egy határ menti régió hallgató-társadalmának térszerkezete. - Juhász E. (szerk.) Régió és oktatás. A "regionális egyetem" kutatás zárókonferenciájának tanulmánykötete. Doktoranduszok Kiss Árpád Közhasznú Egyesülete, Debrecen. 43-56. o.

Süli-Zakar I. (2005) Régió, regionalizmus és regionalizáció. - Pusztai G. (szerk.) Régió és oktatás. Európai dimenzióban. Doktoranduszok Kiss Árpád Közhasznú Egyesülete, Debrecen. 12-22. o.

Süli-Zakar I. (2006) Partium - A határokkal szétszabdalt régió. - Juhász E. (szerk.) Régió és oktatás. A „regionális egyetem" kutatás zárókonferenciájának tanulmánykötete. Doktoranduszok Kiss Árpád Közhasznú Egyesülete, Debrecen. 25-42. o.

Süli-Zakar I. (2009) Eurometropoliszok és eurorégiók együttmüködése az EU keleti perifériáján. - Pusztai G.-Rébay M. (szerk.) Kié az oktatáskutatás? Tanulmányok Kozma Tamás 70. születésnapjára. Csokonai Kiadó, Debrecen. 120-131. o,

Teperics K. (2006) A Partium régió felsôoktatásának demográfiai helyzete. - Juhász E. (szerk.) Régió és oktatás. A "regionális egyetem” kutatás zárókonferenciájának tanulmánykötete. Doktoranduszok Kiss Árpád Közhasznú Egyesülete, Debrecen. 337-345. o.

Timár J. (1993) A nők tanulmányozása a földrajzban. - Tér és Társadalom. 1-2. 1-18. o.

Timár J. (é.n.) Társadalmi nemek, aprófalu- és közösségtanulmányok. http://www.hermes.btk.pte.hu/letoltes/ijen/bib/kozossegtan/KT_2jav_kiad_07_Timar.pdf. 